\title{
The effect of cefazolin on biogas production from thermophilic and mesophilic anaerobic co-digestion of dairy manure and waste milk
}

\author{
Nilmini Beneragama, Masahiro Iwasaki, Suraju A. Lateef and Kazutaka Umetsu* \\ Department of Environmental Hygiene, Obihiro University of Agriculture and Veterinary Medicine, 080-8555, Japan.
}

\begin{abstract}
Antibiotic residues in animal waste from concentrated animal feeding operations are of considerable concern because of the potential development of antibiotic resistant bacteria in the environment and the effect of these residues on manure treatment systems. The objective of this study was to determine the effect of cefazolin (10 $\left.\mathrm{mg} \mathrm{L}^{-1}\right)$ during thermophilic and mesophilic anaerobic co-digestion of manure and waste milk from cows treated with cefazolin for mastitis. The collected antibiotic free manure samples were mixed with slurry and milk obtained from a healthy cow accordingly to form manure mixture (slurry $50 \%$ and manure $50 \%$ ) and milk mixture (slurry $50 \%$, manure $45 \%$ and milk $5 \%$ ), each of which was further separated as the control and cefazolin spiked $\left(10 \mathrm{mg} \mathrm{L}^{-1}\right)$, loaded into triplicate $1 \mathrm{~L}$ batch digesters and anaerobically digested at $37{ }^{\circ} \mathrm{C}$ and $55^{\circ} \mathrm{C}$ for 22 days separately. Control and cefazolin spiked milk mixtures always produced significantly $(\mathrm{p}<0.05)$ higher total and methane gas yields compared to the respective manure mixtures. Compared to the control in both digester types, no significant $(\mathrm{p}>0.05)$ differences in total and methane gas yields were observed in the respective cefazolin spiked digesters despite the temperature at which the digestion was carried out. Volatile fatty acid (VFA) accumulation and reduction of $\mathrm{pH}$ were not observed in any digester of both substrates at both temperatures at the end of the experiment, which confirmed the process stability. However, further investigations are necessary to analyse the effects of increased concentrations of cefazolin in the substrates on digester stability.
\end{abstract}

Keywords: Anaerobic digestion, biogas, cefazolin, co-digestion, mesophilic, thermophilic.

\section{INTRODUCTION}

Anaerobic digestion is an established and proven technology for the treatment of animal manure. It involves the degradation and stabilisation of organic materials under anaerobic conditions by microbial organisms and leads to the formation of biogas (a mixture of $\mathrm{CO}_{2}$ and $\mathrm{CH}_{4}$ ) and microbial biomass (Kelleher et al., 2000). In anaerobic digestion, acedogenic and methanogenic bacteria differ widely in terms of physiology, nutritional needs, growth kinetics, and sensitivity to environmental conditions (Pohland \& Ghosh, 1971). Failure to maintain the balance between these two groups of microorganisms is the primary cause of reactor instability (Demirel \& Yenigun, 2002).

The leading cause of reactor failure is often known to be the presence of inhibitory substances in substantial concentrations. A wide variety of substances have been reported to be inhibitory to the anaerobic digestion processes. Antibiotics are one of the inhibitory substances commonly found in dairy manure as many antibiotics are given therapeutically and sub-therapeutically to animals in confined animal operations (Hamilton, 2014). Cefazolin, a $\beta$-lactam antibiotic, which is widely used to treat cows with mastitis in livestock farms eventually end up in milk and manure as cefazolin residues. Waste milk from cows treated with cefazolin for mastitis is not saleable and should be withheld for a period recommended by the manufacturer. The most suitable way of treating this manure and waste milk would be anaerobic digestion as it provides a method of reducing the pollution from agricultural wastes and offers numerous significant advantages, such as low sludge production, low energy requirement and possible energy recovery (van Staikenburg, 1997). However, cefazolin residues present in these waste components can have negative effects on anaerobic digestion. It is possible that these cefazolin residue concentrations could affect the mixed populations of anaerobic bacteria, and therefore might have a significant influence on both the degree of degradation of the organic load of the waste and on the biogas production. 
Related studies conducted on this aspect are found in literature although not many. Fisher et al., in 1981 have found that the biological activity of the anaerobic digestion of pig slurry was reduced by the presence of lincomycin. The potential inhibitory effect of some antibiotics (chloramphenicol, chlortetracycline, tylosin, and erythromycin) was studied by Camprubi et al., (1988) in batch and semi continuous experiments. However, many of the antibiotics studied have been banned and it is worthwhile to study about the antibiotics currently in use such as cefazolin, which is widely used to treat many bacterial infections in humans and animals including mastitis in cows. Moreover, previously performed studies on this aspect have shown that not all concentrations of a certain antibiotic affect the biogas production from anaerobic digestion of different types of wastes, but beyond a certain concentration. A study conducted by Beneragama et al., in 2012 has shown that a cefazolin concentration of $10 \mathrm{mg} \mathrm{L}^{-1}$ does not have an effect on the reduction level of multi drug resistant bacteria during anaerobic co-digestion of dairy manure and waste milk. Furthermore, it was clear from the results of a previous study (Beneragama et al., 2013) that mesophilic co-digestion of dairy manure and waste milk from cows treated with cefazolin for mastitis would give better performances, in both curtailing the cefazolin resistant bacteria and producing higher amount of methane, if the hydraulic retention time is set compromised in between $20-25$ days. Therefore, an environmentally feasible cefazolin concentration of $10 \mathrm{mg} \mathrm{L}^{-1}$ was tested to examine its influence on the thermophilic and mesophilic anaerobic co-digestion of dairy manure and waste milk separately in laboratory scale digesters. The hydraulic retention time in the current study was set at 22 days.

\section{METHODS AND MATERIALS}

\section{Materials}

Dairy manure and digested slurry samples from cows that had not been dosed with antibiotics including cefazolin were collected from the Obihiro University, Japan farm and bio-gas plant (thermophilic), respectively. Milk was collected from a healthy cow. Digested slurry samples were divided into two groups and kept in water baths at $37{ }^{\circ} \mathrm{C}$ and $55^{\circ} \mathrm{C}$ separately for 3 days in order for the bacteria to get acclimatised to mesophilic and thermophilic temperature and to obtain mesophilic and thermophilic bacteria in the inoculum, separately.

\section{Experimental design}

The materials were mixed in different proportions to obtain different digestates; manure mixture (slurry $50 \%$ and manure $50 \%$ ) and milk mixture (slurry $50 \%$, manure $45 \%$ and milk $5 \%$ ). For the mesophilic and thermophilic digestion, the slurry at mesophilic and thermophilic temperature was used, respectively. In order to examine the effect of cefazolin concentration $\left(10 \mathrm{mg} \mathrm{L}^{-1}\right)$ on anaerobic digestion, manure mixture and milk mixture were spiked with cefazolin separately to obtain a final cefazolin concentration of $10 \mathrm{mg} \mathrm{L}^{-1}$ while as the controls, digestates without added cefazolin were used. Each digestate was loaded into triplicate $1 \mathrm{~L}$ batch digesters with a working volume of $700 \mathrm{~mL}$. Before start of the experiment, headspaces of all digesters were flushed with $\mathrm{CO}_{2}$ to ensure an anaerobic environment, keeping the digesters opened in a Glove box for $c a .30$ minutes. Gas bags were fixed to each digester to collect the evolved biogas. Digestate samples were taken before and after the experiment to analyse for $\mathrm{pH}$ and volatile fatty acids (VFA). Both digestates, each with the control and cefazolin spiked, were subjected to anaerobic digestion at $37^{\circ} \mathrm{C}$ (mesophilic) and $55^{\circ} \mathrm{C}$ (thermophilic) separately in thermostatically controlled electrically heated water baths for 22 days.

\section{Analysis of parameters}

Biogas production in each digester was measured once in two days. Wet gas meter was used to measure the volume of produced gas. All gas measurements were expressed at $0{ }^{\circ} \mathrm{C}$ and a pressure of one atmosphere. Prior to measuring the volume of produced gas, the composition of gas $\left(\mathrm{CH}_{4}\right.$ and $\mathrm{CO}_{2}$ ) was determined through gas chromatography (GC-14A, Shimadzu, Japan) equipped with a thermal conductivity detector. The operational temperatures of injector port, column and the detector were 220, 150 and $220 \mathrm{v}^{\circ} \mathrm{C}$, respectively. Argon was the carrier gas at a flow rate of $50 \mathrm{~mL} \mathrm{~min}^{-1}$.

Volatile fatty acids (VFA) of the samples before and after digestion were determined by HPLC (Shimadzu, Japan) using Shim-pack SCR-102H and Shim-pack SCR-102(H) columns as the main column and guard column, respectively. The mobile phase was $5 \mathrm{vmM}$ p-toluene sulfonic acid and the buffer phase was prepared using $5 \mathrm{vmM}$ p-toluene sulfonic acid, $100 \mathrm{v} \mu \mathrm{M}$ EDTA and $20 \mathrm{vmM}$ Bis-Tris. The column temperature was $45 \mathrm{v}^{\circ} \mathrm{C}$. The injection volume was $20 \mu \mathrm{L}$ and the mobile phase flow rate was $0.8 \mathrm{~mL} / \mathrm{min}$. A pH meter (Horiba D-25) was used to measure the $\mathrm{pH}$ of the samples before and after digestion. Total solids and volatile solids of the samples before and after digestion were determined according to the standard methods (APHA, 2005). 


\section{Statistical analysis}

The statistical analyses were performed using a two-sample t-test assuming unequal variances from the statistical software SAS 9.2. Significance was accepted at probabilities (p) of 0.05 or less for all analyses.

\section{RESULTS AND DISCUSSION}

\section{Effect of cefazolin concentration $\left(10 \mathrm{mg} \mathrm{L}^{-1}\right)$ on biogas production}

No clear differences in cumulative total and methane gas yields were observed between the cefazolin spiked manure and milk mixtures compared to its respective controls at $37^{\circ} \mathrm{C}$ and $55^{\circ} \mathrm{C}$, respectively (Figures 1 and 2). Statistical analysis by SAS 9.2 further confirmed that the observed gas yields in control digesters were not significantly different $(p>0.05)$ from what was observed in the respective cefazolin spiked digesters in both substrate types at both temperatures. An inhibition of methane production was not observed in both manure and milk mixtures incorporated with cefazolin at the concentration of $10 \mathrm{mg} \mathrm{L}^{-1}$.

Methane is produced primarily by the action of two groups of bacteria during anaerobic digestion. Acetilastic methanogens transform acetate to methane and carbon dioxide, and hydrogentrophic methanogens
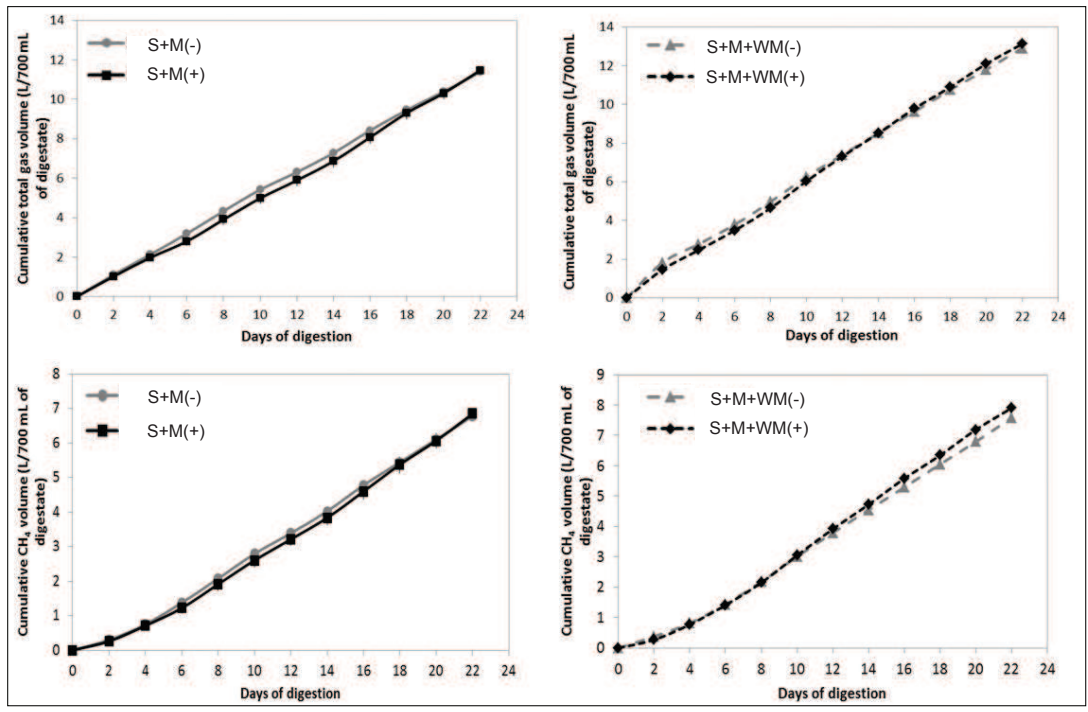

Figure 1: Cumulative total and methane $\left(\mathrm{CH}_{4}\right)$ gas volume obtained in each digestate with $(+)$ and without (-) added cefazolin $\left(10 \mathrm{mg} \mathrm{L}^{-1}\right)$ at $37^{\circ} \mathrm{C}$ for 22 days

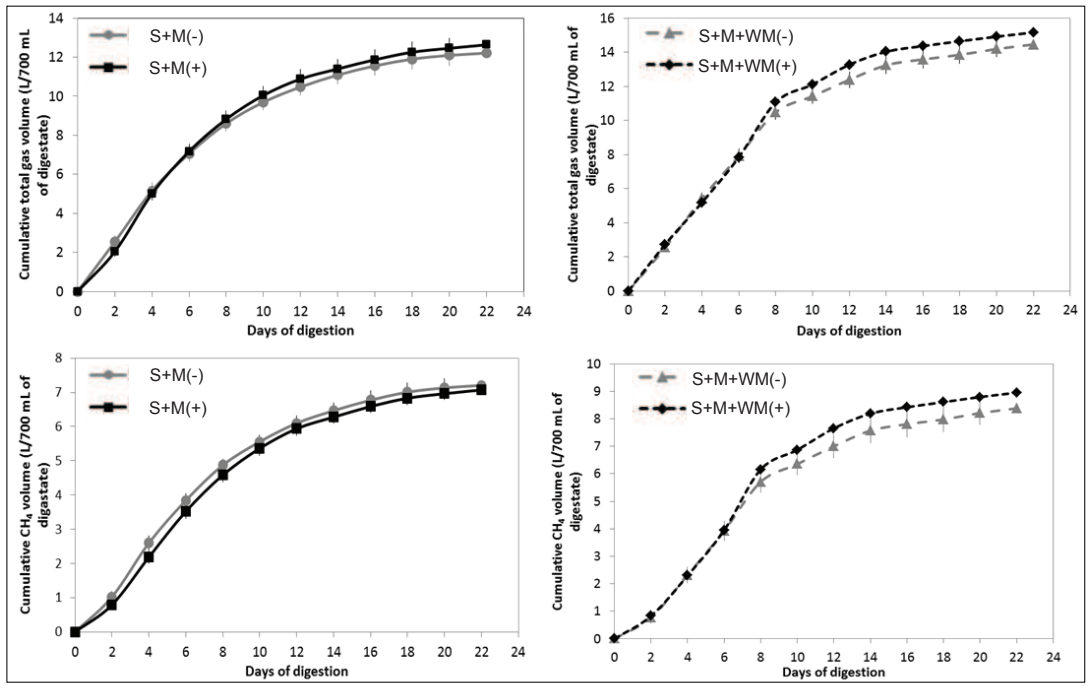

Figure 2: Cumulative total and methane $\left(\mathrm{CH}_{4}\right)$ gas volume obtained in each digestate with $(+)$ and without $(-)$ added cefazolin $\left(10 \mathrm{mg} \mathrm{L}^{-1}\right)$ at $55^{\circ} \mathrm{C}$ for 22 days 
utilise the hydrogen produced by acid forming bacteria during anaerobic oxidation of soluble organics to produce methane and carbon dioxide. About $75 \%$ of the methane produced during anaerobic digestion is a result of the acetilastic methanogen activity (Mah et al., 1980) with the rest from the hydrogentrophic methanogen activity (Jeris $\&$ McCarty, 1965). Furthermore, if these methanogens are significantly affected by antibiotics, a significant inhibitory effect on the methane production can be observed with the rapid accumulation of volatile fatty acids (VFA). The noninhibitory effect of cefazolin on biogas production at a concentration of $10 \mathrm{mg} \mathrm{L}^{-1}$ in the current study was further confirmed by VFA determination in each digestate before and after digestion (Figure 3).

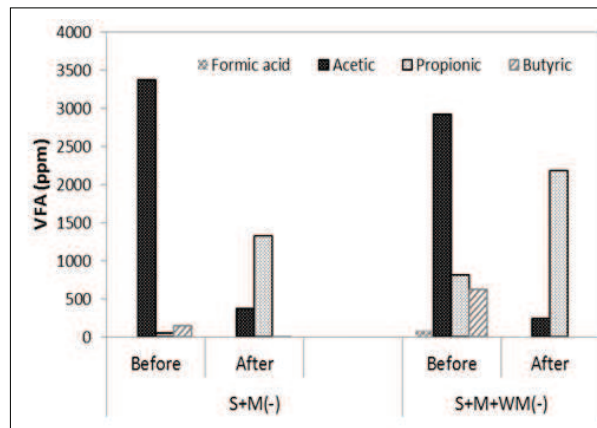

(a)

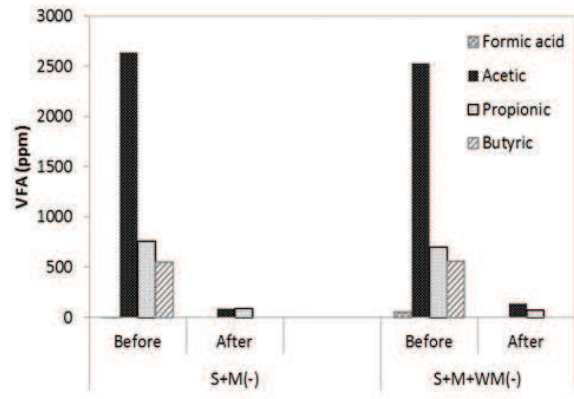

(c)

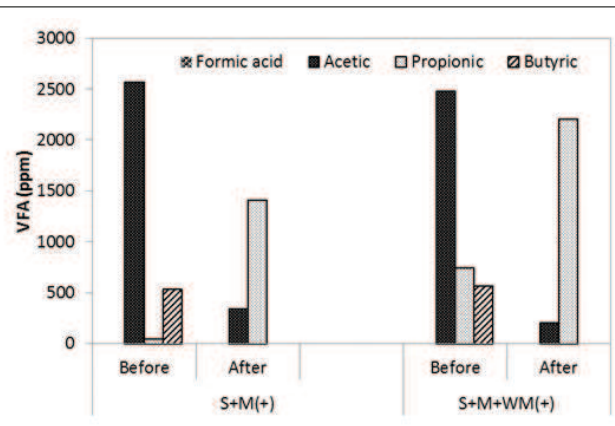

(b)

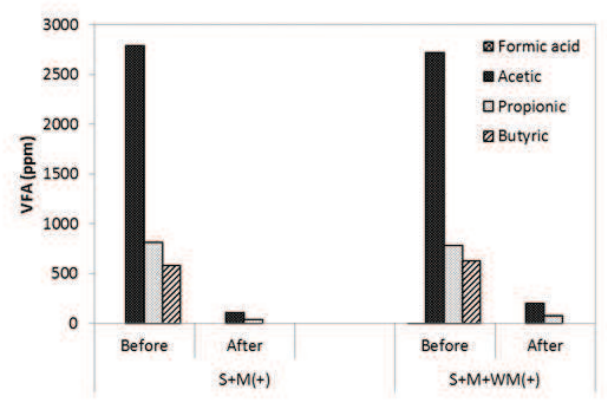

(d)

Figure 3: Changes in volatile fatty acids (VFA) in manure mixture $(S+M)$ and milk mixture $(S+M+M)$ with $(+)$ and without (-) added cefazolin, respectively over the digestion at $37^{\circ} \mathrm{C}[(\mathrm{a}),(\mathrm{b})]$ and $55^{\circ} \mathrm{C}[(\mathrm{c}),(\mathrm{d})]$ for 22 days

\section{Volatile fatty acid concentration}

Acetic acid was present in highest concentrations in all the digesters at both temperatures before the digestion was started (Figure 3). Propionic acid was the second highest in all the digesters at $55{ }^{\circ} \mathrm{C}$ and only in milk mixtures at $37^{\circ} \mathrm{C}$. The control and the cefazolin spiked manure mixtures at $37{ }^{\circ} \mathrm{C}$ showed very low concentrations of propionic acid before digestion. Since two different slurry samples, which have been acclimatised to each temperature separately were used as inoculums, the difference in degradation would have caused this difference in propionic acid concentration in manure mixtures between the two temperatures. However, the addition of milk at $5 \%$ to form the milk mixture has increased mainly propionic acid, butyric acid and formic acid concentrations in those digesters before digestion at $37^{\circ} \mathrm{C}$. Conversely, both control and cefazolin spiked digesters at $55{ }^{\circ} \mathrm{C}$ showed a little reduction of total VFA concentration with the incorporation of $5 \%$ milk, which may also be attributed to the composition of slurry used for the thermophilic digesters. 
Volatile fatty acid concentrations are central to evaluating the performance of anaerobic digestion. The presence of each volatile fatty acid is normally found at the highest concentration during digester startup and operation (Rittmann \& McCarty, 2001). In mesophilic digestion, the VFA content (mainly propionic acid) of both manure and milk mixture after 22 days was still higher suggesting that the conversions of amino acids to acetate, sugars and fatty acids to the intermediate fermentation products propionic acid and butyric acid were actively progressing. The hypothesis drawn was confirmed through biogas production data (Figures 1 and 5), which shows that the production of biogas was not fully completed and was still continuing indicating progressive stabilisation of waste. Any inhibition of fermentation and methanogenesis process by the accumulation of VFAs was not shown at that concentration at 22 days of digestion. In contrast, the VFA content of the thermophilic digestion was decreased drastically at the end of digestion of both manure and milk mixtures revealing that the digesters have undergone complete digestion without producing any more biogas (Figures 2 and 6). Cumulative total and methane gas productions achieved almost a constant value. The VFA concentrations of manure and milk mixtures spiked with cefazolin at $10 \mathrm{mg} \mathrm{L}^{-1}$ compared with the respective no-cefazolin control of each mixture at both temperatures clearly reveal that the digestion process was not affected or inhibited by cefazolin at the tested concentration.

\section{pH}

$\mathrm{pH}$ is also a major indicator of reactor health. The optimum $\mathrm{pH}$ range for anaerobic digestion is neutral to slightly basic $-\mathrm{a}$ pH of 6.6 to 7.6. The inhibition of methanogenesis by inhibitors such as antibiotics leads to the accumulation of VFA in the system, which causes a drop in the $\mathrm{pH}$ value and subsequently breaks down the system without producing methane.The $\mathrm{pH}$ values of manure mixture and milk mixture, with and without cefazolin, respectively have reached from $c a$. 7.3 to 7.7 in mesophilic digestion indicating no accumulation of VFA (as accumulation of VFA results in acidic $\mathrm{pH}$ value), and stabilisation of waste was progressing (Figure 4). On the other hand, in thermophilic digestion, the values reached from $c a$. 7.3 to 8.0 evidencing a complete digestion, which is further proved by the cumulative total and methane gas productions (Figures 2 and 6).

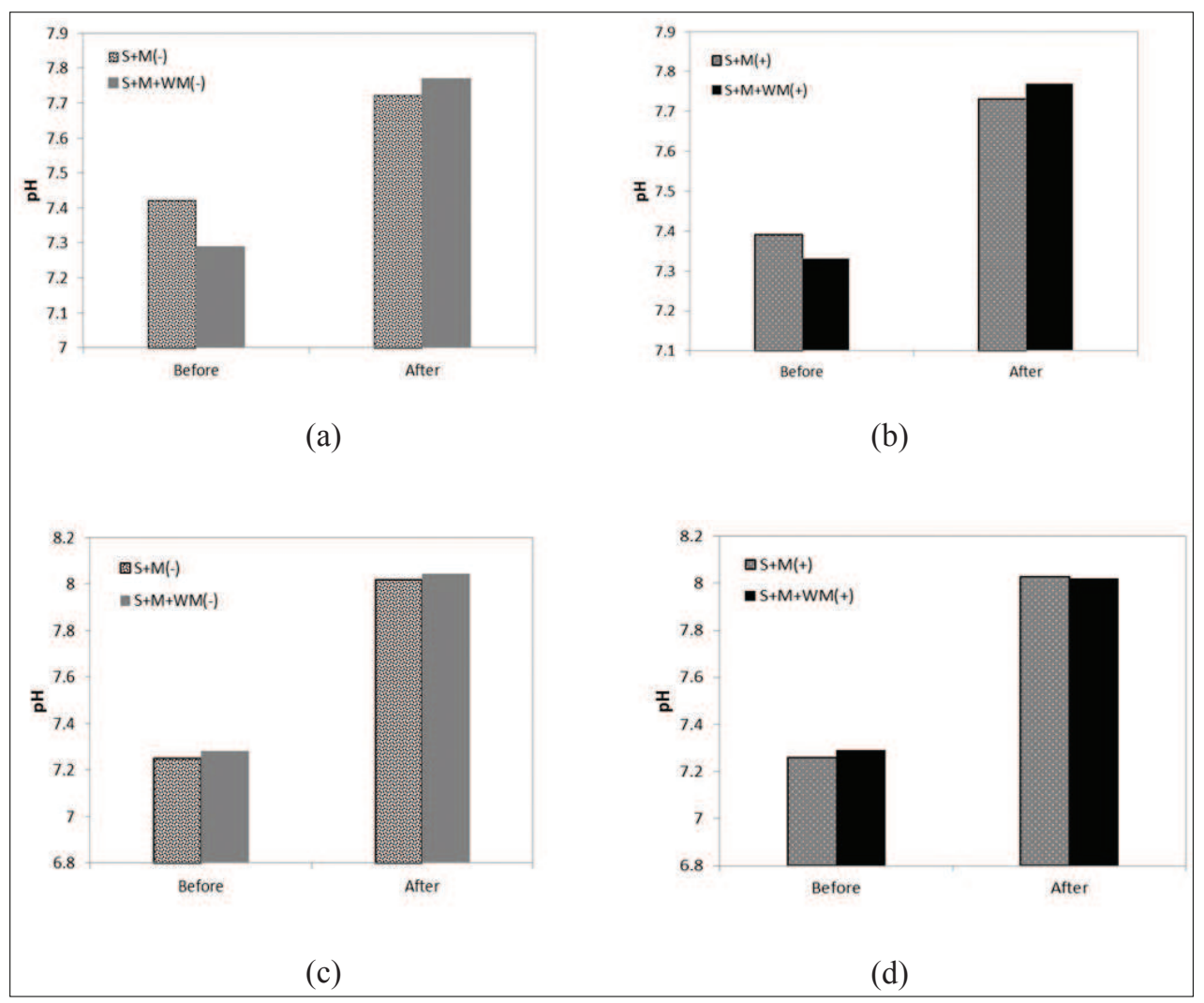

Figure 4: Changes in $\mathrm{pH}$ value of manure mixture $(\mathrm{S}+\mathrm{M})$ and milk mixture $(\mathrm{S}+\mathrm{M}+\mathrm{WM})$ with $(+)$ and without (-) added cefazolin, respectively over the digestion at $37^{\circ} \mathrm{C}[(\mathrm{a}),(\mathrm{b})]$ and $55^{\circ} \mathrm{C}[(\mathrm{c}),(\mathrm{d})]$ for 22 days 
Thermophilic and mesophilic co-digestion of dairy manure and waste milk

The comparison of gas yields between mesophilic and thermophilic digestions show a clear difference in both total and methane gas productions from the manure mixture and the milk mixture. Thermophilic digestion always produced a higher total of methane gas than its respective mesophilic digestion over 22 days (Figures 5 and 6). The addition of $5 \%$ milk in co-digestion has also contributed to a higher total and methane gas production than the digestion of dairy manure alone at both temperatures despite whether
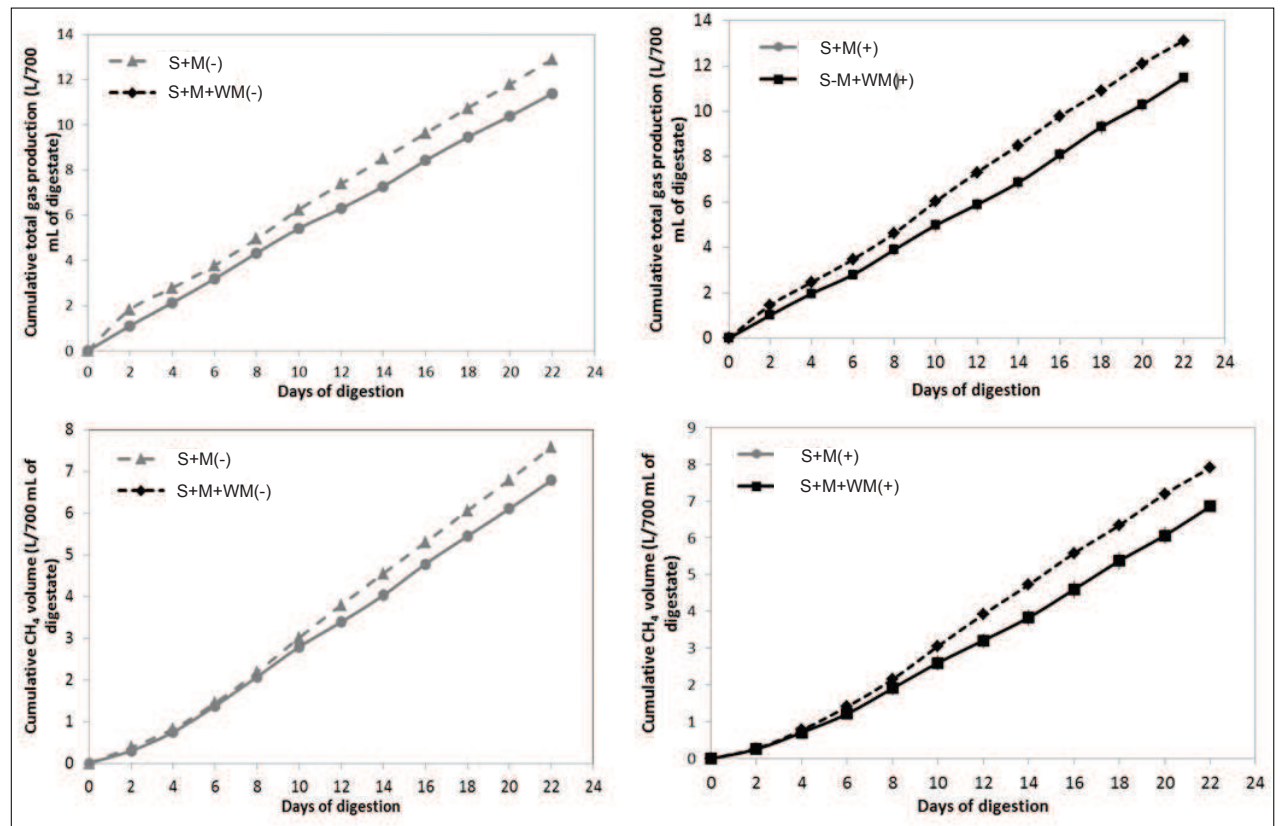

Figure 5: Cumulative total and methane $\left(\mathrm{CH}_{4}\right)$ gas produced in manure mixture $(\mathrm{S}+\mathrm{M})$ and milk mixture $(\mathrm{S}+\mathrm{M}+\mathrm{WM})$ with $(+)$ and without (-) added cefazolin, respectively over the digestion at $37^{\circ} \mathrm{C}$ for 22 days.
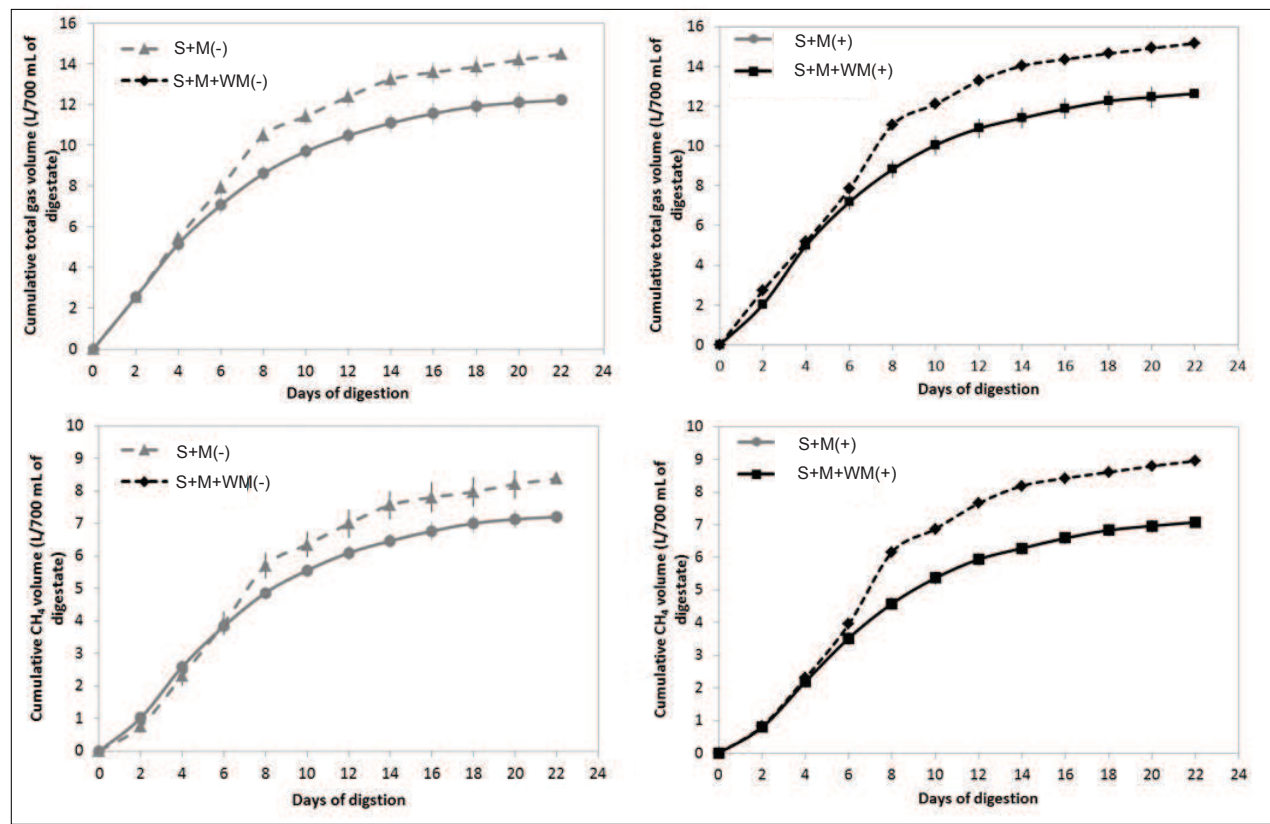

Figure 6: Cumulative total and methane $\left(\mathrm{CH}_{4}\right)$ gas produced in manure mixture $(\mathrm{S}+\mathrm{M})$ and milk mixture $(\mathrm{S}+\mathrm{M}+\mathrm{WM})$ with $(+)$ and without $(-)$ added cefazolin, respectively over the digestion at $55^{\circ} \mathrm{C}$ for 22 days. 
or not the digester contents were spiked with cefazolin $\left(10 \mathrm{mgL}^{-1}\right)$. In mesophilic digestion, both the cumulative total and methane gas yields obtained from the manure mixture were not significantly different $(p>0.05)$ from the respective yields obtained from milk mixture until day 10 of digestion beyond which the values were significantly different. However, this significant difference $(\mathrm{p}<0.05)$ of gas yields between the manure mixture and milk mixture occurred after 6 days in thermophilic digestion. It is known that biogas production is accelerated when the temperature is increased, thus thermophilic digestion produces much gas within a short hydraulic retention time than mesophilic digestion, which takes more time to produce the same amount of gas. This explains why both the total and methane gas yields between the manure mixture and milk mixture at $55^{\circ} \mathrm{C}$ achieved a significant difference much earlier than that at $37^{\circ} \mathrm{C}$. Significantly higher cumulative total and methane gas yields observed in the milk mixture (containing milk only $5 \%$ ) than in the manure mixture can be attributed to the fact of milk being a nutrient rich medium containing many volatile fatty acids (Figure 3 ) and simple sugars etc., in substantial amount.

In the current study, increasing concentrations of added cefazolin were not investigated. It is therefore not known whether this antibiotic in concentrations more than $10 \mathrm{mg} \mathrm{L}^{-1}$ would exert an inhibitory effect on the total and methane gas productions despite the temperature at which the digestion is performed. Some previous studies have reported a reduction in methane production during anaerobic digestion of different wastes. Poels et al., (1984) have reported an increase in the accumulation of volatile fatty acids and so, a decrease in gas production upon the application of increasing amounts of antibiotics thiamphenicol and amoxicillin to methane digestions. These results were further confirmed by Lallai et al., in 2002. Similar findings have been reported in the literature including a $25 \%$ reduction of methane generation by the presence of tetracycline at $80 \mathrm{mg} \mathrm{L}^{-1}$ in swine manure sequencing batch reactors (Masse et al., 2000). The other concentrations tested $\left(20 \mathrm{mg} \mathrm{L}^{-1}\right.$ and $\left.40 \mathrm{mg} \mathrm{L}^{-1}\right)$ have resulted in no-differences to treatment efficiencies compared to the no-tetracycline treatment, which is consistent with the results of current study. Moreover, Arikan et al., (2006) have used an initial oxytetracycline concentration of approximately $10 \mathrm{mg} \mathrm{L}^{-1}$ in cattle slurry and observed a cumulative reduction of methane gas of $27 \%$ over a period of 64 days as compared to the use of slurry without antibiotics. However, some studies have reported an absence of inhibition of methane production even at higher concentrations of some antibiotics. For instance, Lallai et al., (2002) found minimal differences in methane production between oxytetracycline and no- antimicrobial treatments, and concluded that acid forming and methane forming bacteria were not affected by oxytetracycline concentrations of $125 \mathrm{mg} \mathrm{L}^{-1}$ and $250 \mathrm{mg}$ $\mathrm{L}^{-1}$. This further confirms what was found in the current study with added cefazolin at $10 \mathrm{mg} \mathrm{L}^{-1}$ to manure mixture and milk mixture separately. The absence of inhibition observed here can be best explained by the bacterial acclimation to cefazolin or most of the methanogens present in the inoculum have developed resistance to cefazolin. However, increasing concentrations of cefazolin might have an effect on methane productions during anaerobic digestion of waste. It is therefore necessary to test the effect of increasing concentrations of cefazolin on methane production.

\section{CONCLUSION}

Dairy manure and waste milk from cows treated with cefazolin are important substrates for biogas production. Co-digestion of dairy manure and waste milk gives a significantly higher cumulative biogas yield than digestion of dairy manure alone. Cefazolin, being widely used to treat mastitis cows, it is assumed that cefazolin residues in the substrates would cause some inhibitory effect on biogas yield. However, the results of the current study showed that added cefazolin concentration (10 $\mathrm{mg} \mathrm{L}^{-1}$ ) to each substrate does not affect the total and methane gas yields compared to the control at both digestion temperatures studied. Measured VFA concentration and $\mathrm{pH}$ of the substrates at the beginning and the end of the digestion confirmed the process stability. In order to analyse the effects of increasing concentrations of cefazolin in the substrates on digester stability, further investigations are required.

\section{REFERENCES}

1. American Public Health Association (APHA) (2005). StandardMethodsfor Examination of Waterand Wastewater, $21^{\text {st }}$ edition. American Public Health Association/American Water Works/ Water Environment Federation, Washington DC, USA.

2. Arikan O.A., Sikora L.J., Mulbry W., Khan S.U., Rice C. \& Foster G.D. (2006). The fate and effect of oxytetracycline during the anaerobic digestion of manure from therapeutically treated calves. Process Biotechnology 41(7): 1637 - 1643.

DOI: http://dx.doi.org/10.1016/j.procbio.2006.03.010

3. Beneragama N., Lateef S.A., Iwasaki M. \& Umetsu K. (2012). Effect of cefazolin and waste milk on multi-drug bacterial reduction during anaerobic co-digestion of dairy manure and waste milk. Annual Research Journal of SLSAJ 12: $59-70$. 
4. Beneragama N., Moriya Y., Yamashiro T., Iwasaki M., Lateef S.A., Ying C. \& Umetsu K. (2013). The survival of cefazolin resistant bacteria in mesophilic co-digestion of dairy manure and waste milk. Journal of Waste Management and Research 31(8): $843-848$. DOI: http://dx.doi.org/10.1177/0734242X13477717

5. Camprubi M., Paris J.M. \& Casas C. (1988). Effects of antimicrobial agents and feed additives on the performance of piggery waste anaerobic treatment. In: Advances in Water Pollution Control - Anaerobic Digestion 1988. Fifth International Symposium on Anaerobic Digestion, IAWPRC (eds. E.R. Hall \& P.N. Hobson), Pergamon Press, Oxford, UK, pp. $239-248$.

6. Demirel B. \& Yenigun O. (2002). Two-phase anaerobic digestion processes: a review. Journal of Chemical Technology and Biotechnology 77: 743 - 755. DOI: http://dx.doi.org/10.1002/jctb.630

7. Fisher J.R., Iannotti E.L. \& Sivers D.M. (1981). Anaerobic digestion of manure from swine fed on various diets. Agricultural Wastes 3: $201-214$.

8. Hamilton D.W. (2014). Anaerobic Digestion of Animal Manure: Understanding the Basic Processes. Oklahoma Cooperative Extension Service BAE-1747. Division of Agricultural Sciences and Natural Resources, Oklahoma State University, Stillwater, OK 74074, USA.

9. Jeris J.S. \& McCarty P.L. (1965). The biochemistry of methane fermentation using C tracers. Transactions Journal of Water Pollution Control Federation 37(2): 178 - 192.

10. Kelleher B.P., Leahy J.J., Henihan A.M., O’Dwyer T.F., Sutton D. \& Leahy M.J. (2000). Advances in poultry litter disposal technology - a review. Bioresource Technology 83: 27 - 36.

11. Lallai A., Mura G. \& Onnis N. (2002). The effects of certain antibiotics on biogas production in the anaerobic digestion of pig waste slurry. Bioresource Technology 82(2): $205-208$.

12. Mah R.A., Smith M.R., Ferguson T. \& Zinder S. (1980). Microbial Growth on C1 Compounds (ed. H. Dalton), pp.131 - 142. Heyden and Son, London, UK.

13. Masse D.I., Lu D., Masse L. \& Droste R.L. (2000). Effect of antibiotics on psychrophilic anaerobic digestion of swine manure slurry in sequencing batch reactors. Bioresource Technology 75(3): $205-211$.

14. Poels J., Assche P. \& Verstraete W. (1984). Effects of disinfectants and antibiotics on the anaerobic digestion of piggy waste. Agricultural Wastes 9(4): 239 - 247.

15. Pohland F.G. \& Ghosh S. (1971). Developments in anaerobic stabilization of organic wastes- the two-phase concept. Environmental Letters 1: 255 - 266.

DOI: http://dx.doi.org/10.1080/00139307109434990

16. Rittmann B.E. \& McCarty P.L. (2001). Environmental Biotechnology: Principles and Applications. McGraw Hill, New York, USA.

17. Van Staikenburg W. (1997). Anaerobic treatment of wastewater: state of the art. Microbiology 66: $589-596$. 